\title{
Peertechz
}

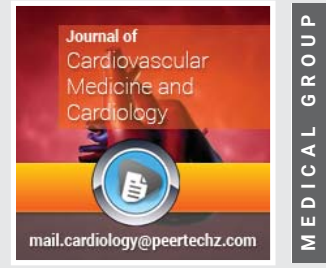

\section{Ultrathin polyethyleneimine (PEI) films for culturing of the human mesenchymal stromal cells (hMSCs)}

\author{
Liudmila M Mezhevikina ${ }^{1 \star}$, Dmitriy A Reshetnikov ${ }^{1}$, Maria \\ G Fomkina $^{2}$ and Evgeniy E Fesenko ${ }^{1}$
}

${ }^{1}$ Institute of Cell Biophysics of the Russian Academy of Sciences, Pushchino, Moscow region 142290,

Russia

${ }^{2}$ Institute of Theoretical and Experimental Biophysics of the Russian Academy of Sciences, Pushchino

Moscow region 142290, Russia

Received: 10 August, 2020

Accepted: 17 August, 2020

Published: 18 August, 2020

*Corresponding author: Liudmila M Mezhevikina, Institute of Cell Biophysics, RAS, Pushchino, Institutskaya Street 3, Moscow Region 142290, Russia, Tel: 8-495625-59-84; 8-916-438-34-32; Fax: 8-496-733-05-09; E-mail: mezhevikina@rambler.ru

Keywords: Mesenchymal stromal cells; Polyethyleneimine; Adhesion; Cell proliferation https://www.peertechz.com

\section{Check for updates}

\section{Summary}

A polymer polyethyleneimine (PEI) can be used in various cell technologies, including the nonviral transfection of animal and human eukaryotic cells. We used the polymer (in the $1 \mathrm{mg} / \mathrm{ml}$ concentration) to produce the ultrathin films at the culture plastic that could enhance the adhesive properties of the human mesenchymal stromal cells (hMSCs) isolated from the heterogeneous cell population of the marrow. Our study demonstrated that the PEI films prevent cell-to-cell cooperation and "glomeration" of hMSCs at the surface of a cultural plate, and enhance hMSCs viability and metabolic activity in vitro. The stimulating effects of PEI on cell proliferation are negligible. Moreover, the immobilization of the human platelet lysate (PL) in $5 \%$ or $10 \%$ concentrations into the PEI solution increases hMSCs viability and effectiveness of their culturing under the deprivation condition and in the serum-free medium. We suggest to use the PEl films containing the immobilized growth factors in the regenerative medicine - at the stages of hMSCs isolation and growth of their biomass.

\section{Inroduction}

A synthetic polymer PEI is used in biomedicine and cell technologies as an agent for non-viral transfection of the eukaryotic cells [1-5]. PEI binds to DNA, RNA, proteins and immunoglobulin's at physiological pH (7.2-7.4) [1,6-8]. Nanoscale complexes PEI-DNA (polyplexes) penetrate the plasma membranes by endocytosis [9]. This phenomenon was shown with the human fibroblasts [9], HEK293, NIH-3T3, HeLa cells [7] and epithelium of the upper respiratory tracts [10]. The polyplexes are unpacked in the lysosomes of host cells and free DNA spreads into the cytoplasm and cell nucleus [1,11]. Various modifications of PEI are used as adjuvants enhancing immune response of a body against action of a vaccine [12]. The polyelectrolyte has strong antimicrobial and antiviral properties [13-15]. On an industrial scale, PEI can be used as a chelating agent at cleaning of water reservoirs from salts of heavy metals [16].
The literature sources contain the data on the PEI application to improve adhesion of the cells with weak adherence to culture plastic, such as endothelial $[17,18]$ and neural cells of a mature body $[17,19,20]$, while just the adhesion serves as a key factor in their proliferation and differentiation $[17,21,22]$. In case of the neural cells, the effectiveness of the customary adhesion factors from the polypeptides of the extracellular cell matrix (ECM) is much lower than the effectiveness of the PEI $[19,20]$. For example, as a result of poor coupling of the primary cortical neurons with the ECM proteins (laminin, polylysine) the cells never adhere to the surface of a culture plastic and lose their potential to differentiate in vitro [20]. At the same time, when the culture plastic is covered with the PEI, the cortical neurons grow and differentiate on its surface, forming the functional neurites and sinus-like structures. A polyelectrolyte PEI has obvious advantages over such natural adhesion factors as collagen and polylysine [17], that was proved with the cultures of the immortal cell lines PC-12 and HEK-293. 
The lower effectiveness of the eukaryotic cells culturing at the coatings from the ECM polypeptides comparatively with culturing on the coatings from the synthetic polymer PEI can be the result of the protein amide groups hydrolysis at the physiological conditions [23]. ECM debris may exert negative effects on cell metabolism, proliferation and differentiation, while the cell adhesive PEI films have, at the physiological conditions of culturing, the enhanced resistance and stability. Moreover, they keep their physico-chemical and biological properties over time, becoming an advantageous adhesive material for the isolation and culturing of the mesenchymal stromal/stem cells of the human marrow (hMSCs). In case of the hMSCs, their adhesion, sticking and spreading within the culture plastic underlie production of a homogeneous cell population $[24,25]$. However the mentioned authors note that a method of ECM isolation from the marrow based on a dominating adhesion of the mesenchymal cells to culture plastic is inefficient. Various approaches can be used to improve efficiency of the ECMs isolation from the heterogeneous population of marrow cells, for example, use of the fibrin microgranules (FMB) that establish an adhesive matrix for the following cell propagation in vitro [25]. The yields of the ECMs produced with the FMB are an order higher than the results of adhesion at culture plastic. The FMB-isolated ECM differentiate into the mesodermal derivatives, including osteocytes [25].

All abovementioned became our reason to examine the PEI films as a potential adhesive coating for hMSCs. We supposed that enhance of the adhesive properties of hMSCs will promote forming of a dense and uniform monolayer in vitro that, in turn, will improve the effectiveness of cultivation and, hence, will promote growth of the cell biomass. The hMSCs are a perspective material for the recovery of damaged organs and tissues, so issues of improvement of culturing efficiency are of great importance for regenerative medicine and biotechnology.

The aim of the investigation was evaluation of the PEI adhesive properties and cytotoxicity towards the primary cultures of the hMSCs with the known parameters of growth, propagation and differentiation in the directions of adipo-, chondro- and osteogenesis [26]. The hMSCs were cultured in the standard media at plastic and at PEI ultrathin films. The adhesive films were prepared by the method of electrostatic adsorption of the PEI solution $(1 \mathrm{mg} / \mathrm{ml})$ on the culture plastic, including solutions supplemented with $5 \%$ and $10 \%$ human platelet lysate (PL) that provides a possibility to investigate the hMSCs growth opportunities in serum-free media or under the deprivation conditions at a low content of fetal serum in the culture medium.

\section{Materials and methods}

\section{Objects of study}

A primary culture of human Mesenchymal Stromal Cells (hMSCs) was kindly provided by the International Biotechnological Company Kintaro Cells power (Moscow Branch, Moscow). The cells were isolated from a female volunteer donor who consented to the appropriate medical procedures. The cells were characterized as positive for CD29,
CD44, CD73, CD90, CD105 and negative for CD34, CD45 and HLA-DRP markers (Cell Technology Laboratory, Federal Scientific and Clinical Center, Federal Medical and Biological Agency (FMBA), 115682, Moscow, 28 Orekhovy Boulevard, $\mathrm{RF})$. All the experiments with the cell cultures were performed in accordance with the Guidelines approved by the IEC of the Institute of Cell Biophysics, RAS (Approval no. 57 dated December 30, 2011)

\section{Culture of h-MSCs}

The h-MSCs were cultured in a high glucose medium DMEM/F12 (Gibco, USA) supplemented with $10 \%$ fetal bovine serum (FBS, Gibco, USA), $1 \mathrm{mM}$ glutamine, $100 \mathrm{U} / \mathrm{ml}$ penicillin and streptomycin. The cultures were maintained in the atmosphere of $5 \% \mathrm{CO}_{2}$ at $37^{\circ} \mathrm{C}$ and high humidity in a $\mathrm{CO}_{2}$ incubator (Sanyo, Japan). The cells were seeded into 24-, 48-, and 96-well plates (Nunc, USA) with films from PEI ( $1 \mathrm{mg} / \mathrm{ml}$ ) preliminarily deposited on the surface of wells. Cells growing on the polyelectrolyte coating-free culture plastic were used as the control. Both the test and control samples were cultured for 24-96 hours, depending on the conditions of an experiment. During this time, the changes in the morphology of the colonies and the MSCs monolayer was monitored with an inverted microscope (Axiovert 25, Zeiss, Germany) at a 10x and 20x objective magnification.

The h-MSCs were passaged, when they reached $80 \%-90 \%$ of monolayer. Before passaging, the DMEM/F12 was removed, and the monolayer was washed twice in a phosphate buffer solution (PBS), then the cells were removed from the surface of the culture plate or polyelectrolyte film with a solution of $0.25 \%$ trypsin-EDTA (NPP PanEco LLC, Russia). For a more complete detachment of the cell mass from the surface, the culture plates were placed into the $\mathrm{CO}_{2}$ incubator for 5-10 min. Trypsin was inactivated by adding of a the DMEM/F12 with $10 \%$ FBS, the cells were pipetted several times in the medium with FBS and their numbers were counted in the Goryaev chamber.

\section{Manufacturing of the PEI nanofilms}

The films were made from polyethyleneimine (PEI, $50 \mathrm{wt}$ \% soln. in water, MN: $60 \mathrm{kDa}, \mathrm{MW}: 750 \mathrm{kDa}, \mathrm{MP}$ Biomedicals Inc., USA). The PBS solution of PEI in the concentration 1 $\mathrm{mg} / \mathrm{ml}$ was applied with a thin layer $(3 \mathrm{~mm}$ ) on the surface of culture plates, kept at room temperature for $30 \mathrm{~min}$., then the excess polyelectrolyte was removed from the plate surface, the plates were dried a little, and the formed PEI films were gently washed in PBS. The films were made under sterile conditions in the laminar box. To avoid contamination, culture plates with nanofilms deposited on the surface of the wells were additionally sterilized for 3 hours under a UV lamp before culturing

\section{In vitro h-MSCs analysis}

The morphology of cells, colonies and a monolayer was evaluated with an inverted microscope (Axiovert 25, Zeiss, Germany) throughout the culture period. Test samples (culture on polyelectrolyte nanofilms) and control samples (culture on plastic) were recorded by photographing and compared 
with each other in relation to their morphology, cell adhesion and growth rate, mitochondrial dehydrogenase activity (MTT assay) and the number of nonviable cells with damaged plasma membranes. Each test involving the nanofilms was performed in 5-6 parallels.

\section{Viability test}

To assess viability of $\mathrm{h}-\mathrm{MSCs}$, we used a vital die $1 \%$ trypan blue (Fluka, Switzerland) revealing the cells with damaged cell membranes, and the MTT assay evaluating activity of mitochondrial dehydrogenases. The ratio of viable cells to nonviable, that is, passing the vital dye through the plasma membranes, was determined with the Goryaev chamber. For this purpose, $20 \mu \mathrm{l}$ of the cell suspension was mixed with $20 \mu \mathrm{l}$ of a $1 \%$ trypan blue solution and placed into the chamber, where the stained and unstained cells were counted according to the standard method. The cell multiplication rate and population doubling time under different conditions of h-MSCs culture (on polyelectrolyte films and without them) were calculated in the logarithmic growth phase according to the formula: $\mathrm{V}=$ $3.32 \mathrm{x} \lg \left[\mathrm{X} / \mathrm{X}_{0}\right]$, where $\mathrm{X}_{\mathrm{o}}$ is the initial cell concentration, $\mathrm{X}$ is the final cell concentration in the culture medium. In order to determine the population doubling time, the following formula was used: $\left[\mathrm{T}=(\ln 2 \mathrm{xdt}) / \ln \left(\mathrm{X} / \mathrm{X}_{\mathrm{o}}\right)\right]$ that considers the duration of h-MSCs culture.

\section{MTT assay}

The assay is based on the ability of mitochondrial dehydrogenases of viable cells to reduce a yellow water-soluble salt of 3-(4,5-dimethylthiazole-2-yl)-2,5-diphenyltetrazole bromide (MTT) into insoluble intracellular MTT-formazan crystals. The test was performed in 96-well culture plates with PEI nanofilms preliminary applied at the well surface. Equal amounts of h-MSCs calculated as $2.5-3.3 \times 10^{4}$ per $100 \mu \mathrm{l}$ of DMEM/F12 culture medium with 5 and $10 \%$ FBS or without FBS were seeded into plates. At the end of the culturing, 20 $\mu \mathrm{l}$ of MTT solution (Thiazolyl blue, MTT, Sigma, USA) was added to each well. The MTT solution at a concentration of 5 $\mathrm{mg} / \mathrm{ml} \mathrm{MTT}$ salt ( $\mathrm{pH}$ 7.4) was prepared immediately before use. The cells were incubated with MTT for 4 hours at $37^{\circ} \mathrm{C}$ in the $\mathrm{CO}_{2}$ incubator, the supernatant was removed, and the precipitate (reduced dark blue formazan crystals generated by mitochondrial dehydrogenases) was dissolved in $150 \mu \mathrm{l}$ of dimethyl sulfoxide (DMSO, Sigma). The quantity of reduced product was measured spectrophotometrically with a plate reader (Model 680 MicroplaReader S/N 20324) at a wavelength of $546 \mathrm{~nm}$. The results were compared with the optical density of the control cells (cultured on the nanofilm-free plastic). The calculations were performed using the nonparametric MannWhitney u-test. Differences in optical density of more than $20 \%$ were considered as significant.

\section{Determination of differential cell adhesion to the PEI surface}

The analysis was performed with a 48-hour h-MSCs culture (3-4 passages after isolation from marrow). The cells were washed twice with PBS solution, trypsinized, counted and distributed in equal volumes into 4-well embryological plates (Nunc, Denmark). Three wells of each plate were pretreated with the PEI solution and served as tests, while the fourth, PEI-free, served as a control. The h-MSCs were plated at a concentration of 5-7 $\times 10^{4}$ cells/ml of DMEM/F12 with $10 \%$ FBS, then the plates were placed in the $\mathrm{CO}_{2}$ incubator. After 1 or 3 hours of incubation, the cells were thoroughly washed in PBS (2 times) and in trypsin-EDTA solution (2-3 min at ambient temperature), then DMEM with $10 \%$ FBS was added to inactivate the enzyme. The cells remaining attached to the surface were counted in 20 fields of view of each well at a 20x objective magnification (Olympus IX70, Japan). To detect differences in the adhesive properties of the polymers, the numbers of attached cells in three parallel test were averaged. To make the results more obvious and significant, the h-MSCs were fixed with methyl alcohol (20 $\mathrm{min}$ at room temperature $20^{\circ} \mathrm{C}$ ) and stained by Giemsa. The numbers of attached cells were calculated with a cytophotometry image analysis software program (PhotoM).

\section{Statistical processing of the results}

The results were processed by simple averaging and standard deviation computing with computer programs Sigma Plot and Microsoft Office Excel. To assess the statistical significance of the differences between the comparison groups, we used the nonparametric Mann-Whitney test that considers $\mathrm{p}<0.05$ as a significant difference between the two comparison groups.

\section{Results}

Culturing of the hMSCs for $24-48 \mathrm{~h}$ in the standard medium DMEM/F12 with $10 \%$ FBS either at plastic or at PEI films showed little changes in cell and monolayer morphology (Figure 1). However, at the PEI surface, the h-MSCs distributed more regularly and formed denser monolayers than at the culture plastic (Figure 1d). The PEI films enhanced the adhesive properties of the hMSCs (Figure 2). After an hour exposition at $37^{\circ} \mathrm{C}$ and $5 \% \mathrm{CO}_{2}$ in the air atmosphere, the most part of cultured cells (over $80 \%$ ) attached to the film surface and spread, forming the processes. Adhesion of the h-MSCs to the

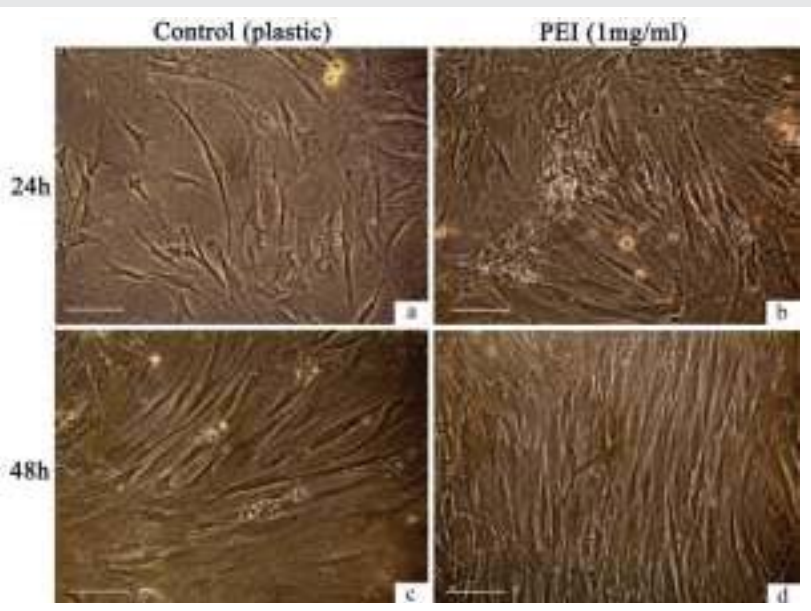

Figure 1: Morphology of the hMSCs monolayer after 24 and $48 \mathrm{~h}$ culturing in DMEM/ F12 with $10 \%$ fetal bovine serum (FBS) at culture plastic and at polyelectrolyte PEI film. The cells were taken at the third passage after isolation from human marrow.

Citation: Mezhevikina LM, Reshetnikov DA, Fomkina MG, Fesenko EE (2020) Ultrathin polyethyleneimine (PEI) films for culturing of the human mesenchymal stromal cells (hMSCs). J Cardiovasc Med Cardiol 7(3): 255-261.DOI: https://dx.doi.org/10.17352/2455-2976.000148 
culture plastic was in this period much weaker and did not exceed $50 \%$ (Figure 2). In this case, the main mass of cells attached to the surface within three hours of exposition in $\mathrm{CO}_{2}-$ incubator at physiological conditions.

High rates of hMSCs adhesion and spreading at PEI films was followed by the regular distribution of cells along its total surface. These phenomena could be considered as characteristics of electrostatic interaction between negatively charged plasma membranes of live cells and positive charge of the PEI film surface.

Examination of growth characteristics of hMSCs shows that rates of cell propagation and monolayer growth at PEI films are the same as that at culture plastic (Table 1). It is expected that contact of hMSCs with PEI does not affect the cell proliferation. However, when the cells h-MSCs are cultured at PEI, such key parameter as doubling time their population is significantly lower than in the control: $22.7 \pm 4.76 \mathrm{~h}$ and $29.1 \pm 4.23 \mathrm{~h}$, respectively. At that, cell death by the necrosis mechanism at the PEI films is twice higher (Table 1). These results may be the indicator of the polyelectrolyte used for hMSCs with a concentration $1 \mathrm{mg} / \mathrm{ml}$.

The polymer PEI binds to DNA, RNA and proteins under the physiological conditions [1], so we investigated a possibility of the h-MSCs culturing at the films with the immobilized human PL factors (Table 2). These experiments used the hMSCs of the 9-10 passages after isolation from marrow and showed that the growth parameters can be affected by the h-MSCs age. In the cells of the later passages, rate of monolayer growth decreased, while population doubling time increased from 29.1 $\pm 4.23 \mathrm{~h}$ (Table 1) to $33.7 \pm 4.1 \mathrm{~h}$ (Table 2).

At culturing at composite films PEI-PL, the maximal amount of the hMSCs in FBS-free DMEM/F12 was found, when the concentration of human PL was $5 \%$ (Table 2). The films PEI-5\% PL kept relatively high rate of the hMSCs growth as a monolayer even in the serum-free medium. The similar

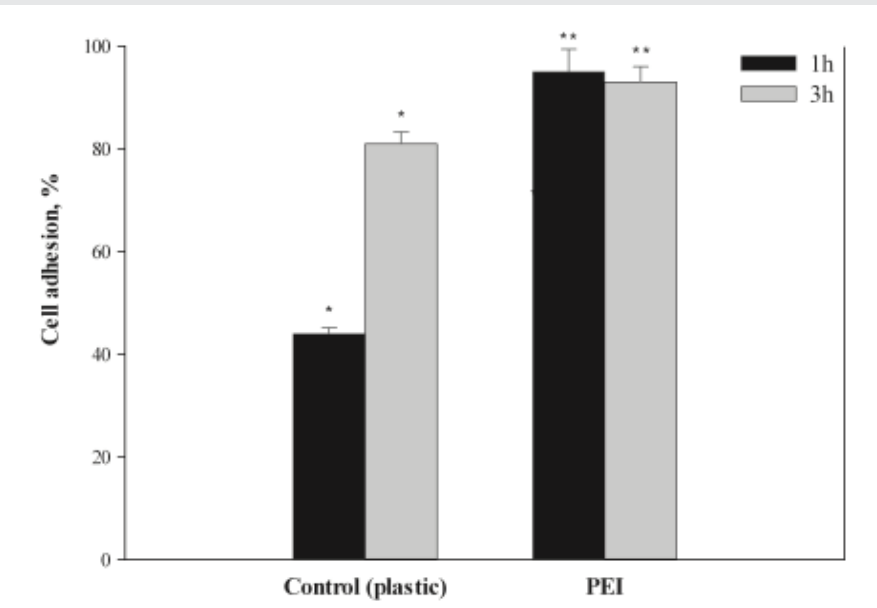

Figure 2: Effectiveness of the hMSCs adhesion (\% of adhesive cells) at culture plastic and PEI film $(1 \mathrm{mg} / \mathrm{ml})$. This is the MSCs culture at the 3-4 passages after isolation from marrow. The cells were incubated for one or three hours in $\mathrm{CO}_{2}-$ incubator in DMEM/F12 with $10 \%$ FBS. The experiments were performed in three parallels. * - significant differences at hMSCs incubation at plastic $(P \leq 0.01)$; ** lack of differences at the cells incubation at the PEI films $(P \geq 0.05)$.
Table 1: Growth characteristics of hMSCs after $72 \mathrm{~h}$ incubation at culture plastic and polyelectrolyte PEI films.

\begin{tabular}{|c|c|c|c|}
\hline $\begin{array}{c}\text { Culturing } \\
\text { conditions }\end{array}$ & $\begin{array}{c}\text { Growth rates } \\
\text { for colonies and } \\
\text { monolayer }\end{array}$ & $\begin{array}{c}\text { Population } \\
\text { doubling time, } \mathbf{h}\end{array}$ & $\begin{array}{c}\text { Proportion of cells } \\
\text { with damaged plasma } \\
\text { membranes, \% }\end{array}$ \\
\hline $\begin{array}{c}\text { Control } \\
\text { (plastic) }\end{array}$ & $2.18 \pm 0.17^{\star}$ & $29.1 \pm 4.23$ & 6.2 \\
\hline PEl film & $2.13 \pm 0.15^{\star}$ & $22.7 \pm 4.76^{* *}$ & 13.4 \\
\hline
\end{tabular}

Note: We used hMSCs at 3-5 passages after isolation from marrow. The cells were cultured in DMEM/F12 with 10\% fetal bovine serum (Sigma). By the results of the test with $1 \%$ vital die trypan blue, the cells with damaged plasma membranes were considered as inviable. Each experiment was performed in four parallels.

* - lack of significant differences in the rates of a monolayer growth $(P \geq 0.01)$;

**- significant reduction in hMSCs population doubling at the PEI film comparatively with the control culture at the plastic $(P \leq 0.01)$.

Table 2: Effectiveness of the h-MSCs culturing at the polyelectrolyte films PEI with the immobilized human platelet lysate (PL) in the serum-free DMEM/F12.

\begin{tabular}{|c|c|c|c|}
\hline Culturing conditions & $\begin{array}{c}\text { Cell numbers after } \mathbf{4 8} \mathbf{~ h} \\
\text { culturing } \mathbf{( \times 1 0 ^ { 4 }} \text { ) }\end{array}$ & $\begin{array}{c}\text { Growth } \\
\text { rate }\end{array}$ & $\begin{array}{c}\text { Population } \\
\text { doubling time, } \mathbf{h}\end{array}$ \\
\hline $\begin{array}{c}\text { Control 1 } \\
\text { (with 10\% FBS) }\end{array}$ & $8.8 \pm 0.9$ & $1.4 \pm 0.2$ & $33.7 \pm 4.1^{\star}$ \\
\hline $\begin{array}{c}\text { Control 2 } \\
\text { (without FBS) }\end{array}$ & $5.6 \pm 1.2$ & $0.4 \pm 0.1$ & $105.8 \pm 6.9$ \\
\hline $\begin{array}{c}\text { PEI + 5\% PL } \\
\text { (without FBS) }\end{array}$ & $12.1 \pm 0.6^{* *}$ & $1.8 \pm 0.3$ & $25.4 \pm 2.7^{\star}$ \\
\hline $\begin{array}{c}\text { PEI + 10\% PL } \\
\text { (without FBS) }\end{array}$ & $9.9 \pm 1.2$ & $1.6 \pm 0.2$ & $30.4 \pm 3.2^{*}$ \\
\hline
\end{tabular}

Note: We used hMSCs at 9-10 passages after isolation from marrow. The initial concentration of the cells explanted into culture was $3.3-3.5 \times 10^{4} / \mathrm{ml}$ of medium. The cells were cultured in the serum-free DMEM/F12 in three parallels. The cells cultured at the plastic served as controls: in the medium + 10\% FBS (1), in the serumfree medium without (2)

* - lack of significant differences in the times of the hMSCs populations doubling at the composite films PEI with 5 or $10 \% \mathrm{PL}(P \geq 0.01)$; ${ }^{* *}$ - significant increase in the growth rate and cells amount at the PEI films with $5 \% \mathrm{PL}$ comparatively with the controls 1 and 2 , and with $10 \% \operatorname{PL}(P \leq 0.05)$

efficiency of the hMSCs culturing was observed at use of the PEI films with $10 \%$ human PL.

Evaluation of the hMSCs with the MTT assay showed that culturing at the PEI films with $5 \%$ human PL keeps high activity of mitochondrial dehydrogenases under the deprivation and at total absence of FBS in the culture medium (Figure 3). At that, the metabolic activity of the cells was even higher than in the control, when the cells were cultured at the plastic with $10 \%$ FBS (Figure 3).

\section{Discussion}

The described above results were obtained with the hMSCs of the 3-10 passages after their isolation from a heterogeneous population of marrow cells. Lifetime of such primary hMSCs cultures in vitro is limited. We found that at later passages their growth inhibits, while population doubling time increases. These observations can be confirmed by our experiments using PEI films as an adhesive coating for h-MSCs (Tables 1,2). The PEI was chosen to enhance the hMSCs adhesion because there are the electrostatic contacts between positively charged amine groups at the surface of a PEI film and negatively charges phospholipids of cell membranes. In this case, the electrostatic interactions promote the hMSCs attachment to the surface of positively charged PEI film, enhancing processes of cells 


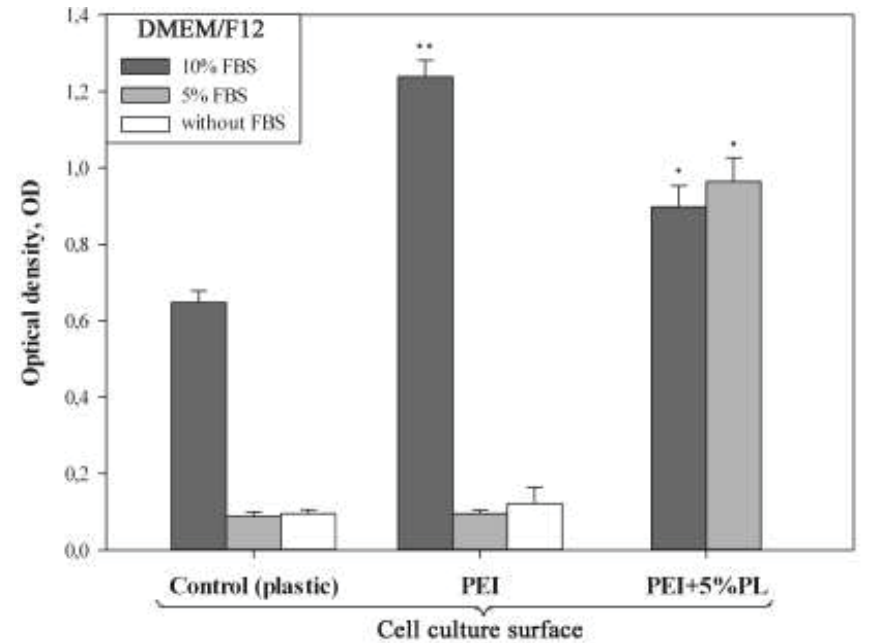

Figure 3: Viability and metabolic activity of the hMSCs (by MTT-assay) at 48-h culturing at the plastic and PEl films with or without $5 \%$ platelet lysate $(\mathrm{PL})$ under the deprivation ( $5 \% \mathrm{FBS}$ ) and at complete FBS absence in culture medium. * - differences are not significant $(P \geq 0.01)$; ** - lack of differences between the h-MSCs culturing in the serum-free medium DMEM/F12 and in the medium supplemented with $5 \%$ FBS with the use of the PEI films with the immobilized $5 \%$ human PL $(P \geq 0.05)$.

adhesion and spreading in vitro (Figure 2). Inclusion of the platelet lysate (PL) into the PEI solution does not exert negative effects on the adhesive properties of the polymer films.

The hMSCs quickly attach to the PEI surface (one hour incubation at $\mathrm{CO}_{2}$-incubator under the physiological conditions) and form a regular monolayer in 2-3 days of culturing (Figure $1, \mathrm{~d})$. Direct contacts between the h-MSCs and PEI do not exert negative effects on a monolayer morphology during 24-48-h culturing (Figure $1 \mathrm{~b}, \mathrm{~d}$ ). Note also that we used a linear polymer PEI, which, in the eyes of some experts, is less toxic for the eukaryotic cells than a branched one $[27,28]$. Nevertheless, a contact between the hMSCs and surface of a linear polymer PEI doubles a number of cells with the damaged cell membranes in a cell population ( $13.4 \%$ versus $6.2 \%$ in the control). The polyelectrolyte can damage cell membranes and cause quick death of the eukaryotic cells, and can cause the delayed apoptosis, destroying the mitochondrial membranes after its internalization into cells $[29,30]$. The cells die, first of all, due to effects of free PEI molecules on the lipid matrix [31-33], and because of inhibition of cytoplasm $\mathrm{pH}$ potential regulation [34]. Forming of total hMSCs monolayer at the PEI films never took more than 72-96 hours, so we could not observe any long-term negative effects of the PEI use except for the increased cell death due to the necrosis (Table 1). Studies on neural and endothelial cells $[10,18,20,35]$, cells of rat pheochromocytoma PC-12 and human embryonic kidney HEK-293 [17] did not show cytotoxic effects of PEI $[17,18,20]$. The polymer is good for cell cultures of tissues with weak adhesion to cultural plastic [19-22].

The adhesion of $h-M S C s$ to the surface of a culture plate and their further spreading at this surface is a key moment at the stage of their isolation from the heterogeneous cell population of a marrow $[24,25]$. Covering of the culture plastic with the PEI films solves this problem. In spite of the PEI cytotoxicity, the polymer enhance adhesive properties of the hMSCs (Figure 2), reduce time of population doubling (Table 1), and promote high activity of mitochondrial dehydrogenases (MTT test) even at deprivation ( $5 \% \mathrm{FBS}$ in the culture medium). Reduction in time of the hMSCs population doubling at the PEI films results in the increase in total amount of cell mass in vitro and levelling of the inviable cells at the following passages. Inclusion of the growth factors of the human PL into the composition of the PEI film makes monolayer growth of the hMSCs real even at the totally serum-free culture medium (Figure 3).

The growth factors and cytokines may release from the composite PEI-PL films into the culture medium along the concentration gradient, though this issue needs some more clarification. For example, we failed to find any significant differences in the amounts of cells and their metabolic activity at PEI and PEI-5\% PL at culturing in the serum-free DMEM/ F12 and in the same medium supplemented with 5\% FBS (Table 2, Figure 3). These parameters differed essentially only for the films PEI-5\%PL and PEI-10\%PL, at that, the functional properties of the first provided better conditions for culturing of h-MSCs in a serum-free medium (Table 2). The results tell that the polyelectrolyte films PEI with the immobilized factors of the human PL meet the metabolic requirements of hMSCs in vitro. Such films can take a practical part and be used for isolation and growth of the marrow mesenchyme cells in the serum-free media for the purposes of the regenerative medicine.

From an economic perspective, positively charged PEI films are more affordable and more advantageous adhesive coatings for the hMSCs isolation and culturing than the films based on the expensive polypeptides of the ECM. PEI interacts actively with the negatively charged cell membranes [33,34,36]. Binding of PEI to the human platelet lysate PL increases functionality of the PEI-PL films and provides for the regular growth and propagation of the hMSCs in DMEM/F12 with low FBS content (5\%), the same as FBS-free. At that, the hMSCs keep their adhesion ability and remain viable at in vitro culturing.

\section{Conclusions}

The primary hMSCs populations in the serum-free media and under the deprivation ( $5 \% \mathrm{FSC}$ in a culture medium) have limited abilities to adhesion and spreading at the surface of culture plastic. These factors tell on the weak secretory activity of the respective components of the ECM. According to our data, a linear polymer PEI can substitute lack or deficit of the ECM by self-assembling of a synthetic hydrogel with the immobilized growth factors and cytokines at the surface of culture plastic. The PEI films promote the increase in: (1) rate of adhesion and (2) effectiveness of isolation of hMSCs from marrow and their culturing that leads inevitably to the increase in cell mass in vitro. A current hMSCs-based therapeutic approaches involves the transplantation of great amounts of functionally active cells into affected areas. Growth of the cell mass in course of the hMSCs culturing in the serum-free media is a key issue of the regenerative medicine. In this context the PEI films with the immobilized growth factors, for example, with the human PL factors, can serve as an effective base for isolation and culturing of the hMSCs from the human marrow. 


\section{Acknowledgments}

We would like to thank the Company Kintaro Power for human bone marrow mesenchymal cells (Moscow branch, Moscow) and also thank Olga Seraya for her help in preparing the manuscript.

\section{References}

1. Boussif O, Lezoualc'h F, Zanta MA, Mergny MD, Scherman D, et al. (1995) $A$ versatile vector for gene and oligonucleotide transfer into cells in culture and in vivo: polyethylenimine. Proc Natl Acad Sci U S A 92: 7297-7301. Link: https://bit.ly/2Y7YH6T

2. Guerra-Crespo M, Charli JL, Rosales-Garcia VH, Pedraza-Alva G, Perez Martinez L (2003) Polyethylenimine improves the transfection efficiency of primary cultures of post-mitotic rat fetal hypothalamic neurons. J Neurosci Methods 127: 179-192. Link: https://bit.ly/3kWx7TV

3. Neu M, Fischer D, Kissel T (2005) Recent advances in rational gene transfer vector design based on poly(ethylene imine) and its derivatives. J Gene Med 7: 992-1009. Link: https://bit.ly/34mN5kL

4. Gabrielson NP, Pack DW (2006) Acetylation of polyethylenimine enhances gene delivery via weakened polymer/DNA Interactions. Biomacromolecules 7: 2427-2435. Link: https://bit.ly/2CFjuaE

5. Pandey AP, Sawant KK (2016) Polyethylenimine: A versatile, multifunctional non-viral vector for nucleic acid deliver. Mat Sci Engin C 68: 904-918. Link: https://bit.ly/2E1HHZm

6. Futami J, Kitazoe M, Maeda T, Nukui E, Sakaguchi M, et al. (2005) Intracellular delivery of proteins into mammalian living cells by polyethyleniminecationization. J Biosci Bioeng 99: 95-103. Link: https://bit.ly/2E7BOtj

7. Kitazoe M, Murata H, Futami J, Maeda T, Sakaguchi M, et al. (2005) Protein transduction assisted by polyethylenimine-cationized carrier proteins. J Biochem 137: 693-701. Link: https://bit.ly/2E2ktSW

8. Kitazoe M, Futami J, Nishikawa M, Yamada H, Maeda Y (2010) Polyethylenimine-cationized $\beta$-catenin protein transduction activates the Wnt canonical signaling pathway more effectively than cationic lipid-based transduction. Biotechnol J 5: 385-392. Link: https://bit.ly/3h7Cf5z

9. Remy-Kristensen A, Clamme JP, Vuilleumier C, Kuhry JG, Mely Y (2001) Role of endocytosis in the transfection of L929 fibroblasts by polyethylenimine/DNA complexes. Biochim Biophys Acta 1514: 21-32. Link: https://bit.ly/2CBXi17

10. Di Gioia S, Rejman J, Carrabino S, De Fino I, Rudolph C, et al. (2008) Role of Biophysical Parameters on ex Vivo and in Vivo Gene Transfer to the Airway Epithelium by Polyethylenimine/Albumin Complexes. Biomacromol 9: 859866. Link: https://bit.ly/2CAtK3N

11. Akinc A, Mini T, Klibanov AM, Langer R (2005) Exploring polyethyleniminemediated DNA transfection and the proton sponge hypothesis. J Gene Med 7: 657-663. Link: https://bit.ly/2CAtMZt

12. Shen C, Li J, Zhang Y, Li Y, Shen G, et al. (2017) Polyethylenimine-based micro/ nanoparticles as vaccine adjuvants. Int J Nanomed 12: 5443-5460. Link: Link: https://bit.ly/3g76hoH

13. Milovic NM, Wang J, Lewis K, Klibanov AM (2005) Immobilized N-alkylated polyethylenimine avidly kills bacteria by rupturing cell membranes with no resistance developed. Biotechnol Bioeng 90: 715-722. Link: https://bit.ly/3iOxHkW

14. Khalil H, Chen T, Riffon R, Wang R, Wang Z (2008) Synergy between polyethylenimine and different families of antibiotics against a resistant clinical isolate of Pseudomonas aeruginosa. Antimicrob Agents Chemother 52: 1635-1641. Link: https://bit.ly/3h85zZ
15. Spoden GA, Besold K, Krauter S, Plachter B, Hanik N, et al. (2012) Polyethylenimine is a strong inhibitor of human papillomavirus and cytomegalovirus infection. Antimicrobial Agents and Chemotherapy 56: 7582. Link: https://bit.ly/3g3DgKF

16. Liu J, Su D, Yao J, Huang Y, Shao Z, et al. (2017) Soy protein-based polyethylenimine hydrogel and its high selectivity for copper ions removal in wastewater treatment. J Mater Chem A 4: 1-3. Link: https://rsc.li/2CArhq4

17. Vancha AR, Govindaraju S, Parsa KVL, Jasti M, González-García V, et al. (2004) Use of polyethyleneimine polymer in cell culture as attachmen. BMC Biotechnol 4: 23. Link: https://bit.ly/2FAix4w

18. Ai H, Lvov YM, Mills DK, Jennings M, Alexander JS, et al. (2003) Coating and selective deposition of nanofilm on silicone rubber for cell adhesion and growth. Cell Biochem Biophys 38: 103-114. Link: https://bit.ly/3kWjeFy

19. Ruardij TG, Goedbloed MH, RuttenWLC (2000) Adhesion and patterning of cortical neurons on polyethylenimine- and fluorocarbon-coated surfaces. Trans Biomed Engineering 47: 1593-1599. Link: https://bit.ly/3h5KcrO

20. Liu B, Ma J, Gao E, He Y, Cui F, et al. (2008) Development of an artificial neuronal network with post-mitotic rat fetal hippocampal cells by polyethylenimine. Biosens Bioelect 23: 1221-1228. Link: https://bit.ly/2DUSF2Z

21. Lelong IH, Petegnief V, Rebel G (1992) Neuronal cells mature faster on polyethyleneimine coated plates than on polylysine coated plates. J Neurosci Res 32: 562-568. Link: https://bit.ly/317EZu5

22. Bledi Y, Domb AJ, Linial M (2000) Culturing neuronal cells on surfaces coated by a novel polyethyleneimine-based polymer. Brain Res 5: 282-289. Link: https://bit.ly/321m3wj

23. Garza JM, Jessel N, Ladam G, Dupray V, Muller S, et al. (2005) Polyelectrolyte multilayers and degradable polymer layers as multicomponent films. Langmuir 21: 12372-12377. Link: https://bit.ly/3g4BXLu

24. Nadri S, Soleimani M, Hosseni RH, Massumi M, Atashi A, et al. (2007) An efficient method for isolation of murine bone marrow mesenchymal stem cells. Int J Dev Biol 51: 723-729. Link: https://bit.ly/316N1mR

25. Rivkin R, Ben-Ari A, Kassis I, Zangi L, Gaberman E, et al. (2007) High-yield isolation, expansion, and differentiation of murine bone marrow-derived mesenchymal stem cells using fibrin microbeads (FMB). Cloning Stem Cells 9: 157-175. Link: https://bit.ly/324K7ya

26. Pittenger MF, Mackay AM, Beck SC, Jaiswal RK, Douglas R, et al. (1999) Multilineage potential of adult human mesenchymal stem cells. Science 284 : 143-147. Link: https://bit.ly/34mP4pd

27. Parhamifar L, Larsen AK, Hunter AC, Andresen TL, Moghimi SM (2010) Polycation cytotoxicity: a delicate matter for nucleic acid therapy focus on polyethylenimine. Soft Matter 6: 4001-4009. Link: https://rsc.li/2E64TWe

28. Kafil V, Omidi Y (2005) Cytotoxic impacts of linear and branched polyethylenimine nanostructures in A431 cells. Biolmpacts 2011; 1: 23-30. Link: https://bit.ly/3iTEb2a

29. Moghimi SM, Symonds P, Murray JC, Hunter AC, Debska G, et al. (2005) A tow-stage poly(ethylenimine)-mediated cytotoxicity: implications for genetransfer/therapy. Mol Ther 11: 900-995. Link: https://bit.ly/2Frr6hQ

30. Hunter AC, Moghimi SM (2010) Cationic carriers of genetic material and cell death: a mitochondrial tale. Biochim Biophys Acta Bioenerg 1797: 1203-1209. Link: https://bit.ly/2E9Cbnl

31. Oku N, Yamaguchi N, Yamaguchi N, Shibamoto S, Ito F, et al. (1986) The fusogenic effect of synthetic polycations on negatively charged lipid bilayers. J Biochem 100: 935-944. Link: https://bit.ly/2DTiVuz

32. Boeckle S, von Gersdorff K, van der Piepen S, Culmsee C, Wagner E, et al. (2004) Purification of polyethylenimine polyplexes highlights the role of free polycations in gene transfer. J Gene Med 6: 1102-1111. Link: https://bit.ly/315VpmH 
33. Zhang C, Wu Fu-Gen, Hu P, Chen Z (2014) Interaction of polyethylenimine with model cell membranes studied by linear and nonlinear spectroscopic techniques. J Phys Chem C 118: 12195-12205. Link: https://bit.ly/3iNgXKX

34. Ira, Mély Y, Krishnamoorthy G (2003) DNA vector polyethyleneimine affects cell $\mathrm{pH}$ and membrane potential: a time-resolved fluorescence microscopy study. J Fluorescence 13: 339-347. Link: https://bit.ly/2YeA34S

35. Grzeczkowicz A, Gruszczynska-Biegala J, Czeredys M, Kwiatkowska A Strawski M, et al. (2019) Polyelectrolyte membrane scaffold sustains growth of neuronal cells. J Biomed Mater Res Part A 107: 839-850. Link: https://bit.ly/3g7Gflc

36. Clamme JP, Bernacchi C, Vuilleumier C, Duportail G, Mely Y (2000) Gene transfer by cationic surfactants is essentially limited by the trapping of the surfactant/DNA complexes onto the cell membrane: a fluorescence investigation. Biochim Biophys Acta 1467: 347-361. Link: https://bit.ly/312YmEC

\section{Discover a bigger Impact and Visibility of your article publication with}

\section{Peertechz Publications}

\section{Highlights}

* Signatory publisher of ORCID

* Signatory Publisher of DORA (San Francisco Declaration on Research Assessment)

* Articles archived in worlds' renowned service providers such as Portico, CNKI, AGRIS, TDNet, Base (Bielefeld University Library), CrossRef, Scilit, J-Gate etc.

* Journals indexed in ICMJE, SHERPA/ROMEO, Google Scholar etc.

* OAI-PMH (Open Archives Initiative Protocol for Metadata Harvesting)

* Dedicated Editorial Board for every journal

* Accurate and rapid peer-review process

* Increased citations of published articles through promotions

* Reduced timeline for article publication

Submit your articles and experience a new surge in publication services (https://www.peertechz.com/submission).

Peertechz journals wishes everlasting success in your every endeavours.

Copyright: (C) 2020 Mezhevikina LM, et al. This is an open-access article distributed under the terms of the Creative Commons Attribution License, which permits unrestricted use, distribution, and reproduction in any medium, provided the original author and source are credited.

Citation: Mezhevikina LM, Reshetnikov DA, Fomkina MG, Fesenko EE (2020) Ultrathin polyethyleneimine (PEI) films for culturing of the human mesenchymal stromal cells (hMSCs). J Cardiovasc Med Cardiol 7(3): 255-261.DOI: https://dx.doi.org/10.17352/2455-2976.000148 